\title{
Analysis of Temporal and Spatial Changes in the Vegetation Density of Similipal Biosphere Reserve in Odisha (India) Using Multitemporal Satellite Imagery
}

\author{
Anima Biswal, ${ }^{1}$ A. Jeyaram, ${ }^{1}$ Sumit Mukherjee, ${ }^{2}$ and Umesh Kumar ${ }^{2}$ \\ ${ }^{1}$ Regional Remote Sensing Centre, East, NRSC, ISRO, Kolkata 700156, India \\ ${ }^{2}$ Anthropological Survey of India, Kolkata 700016, India \\ Correspondence should be addressed to Anima Biswal; anima.biswal@gmail.com
}

Received 24 July 2013; Revised 24 October 2013; Accepted 25 November 2013

Academic Editor: Ram C. Sihag

Copyright (C) 2013 Anima Biswal et al. This is an open access article distributed under the Creative Commons Attribution License, which permits unrestricted use, distribution, and reproduction in any medium, provided the original work is properly cited.

National parks and protected areas require periodic monitoring because of changing land cover types and variability of landscape contexts within and adjacent to their boundaries. In this study, remote sensing and GIS techniques were used to analyse the changes in the vegetation density particularly in the zones of higher anthropogenic pressure in the Similipal Biosphere Reserve (SBR) of Odisha (India), using Landsat imagery from 1975 to 2005. A technique for the detection of postclassification changes was followed and the change in vegetation density as expressed by normalized difference vegetation index was computed. Results indicate that high dense forest in the core zone has been conserved and the highest reforestation has also occurred in this zone of SBR. The results also reveal that anthropological interventions are more in the less dense forest areas and along the roads, whereas high dense forest areas have remained undisturbed and rejuvenated. This study provides baseline data demonstrating alteration in land cover over the past three decades and also serves as a foundation for monitoring future changes in the national parks and protected areas.

\section{Introduction}

Promoting and facilitating the use of remotely sensed images for the monitoring and management of national parks and other protected areas have been the focus of many research and governmental agencies. Monitoring landscape dynamics can answer questions of what the spatial extent of land cover types within and adjacent to the parks and the protected areas and is how they have changed over time. Vegetation mapping is a very important application of remotely sensed data. Spectral profiles of vegetation clearly show that the peak reflectance can be found in the near-infrared wavelengths mainly because of the internal structure of "green" leaves, and the greatest absorption is in the red wavelengths because of the presence of chlorophyll pigments. The normalized difference vegetation index (NDVI) is one of the most successfully used vegetation indices for land cover classification [1-4]. It is also used as an environmental indicator to monitor temporal and spatial variation in vegetation density as well as the health and viability of plant cover over time [5-8] for the derivation of biophysical properties [9-11] and for estimation of net primary production [12-14]. The NDVI is correlated with many biophysical parameters of the vegetation canopy such as leaf area index (LAI), fractional vegetation cover, vegetation condition, and biomass.

The NDVI values increase as green cover density increases [15]; the values are calculated from red and nearinfrared reflection values $[5,6,16]$, which have a wide range used in vegetation indices [17]. Vegetated landscapes typically have NDVI values ranging from 0.1 in the desert to 0.8 in dense tropical rain forest $[18,19]$. It was demonstrated that when NDVI values are between 0.0 and 0.2 , the pixel is considered bare soil; for NDVI values greater than 0.5 , the pixel is considered fully vegetated.

The Similipal is a densely forested hill range in the heart of the erstwhile Mayurbhanj State (now Odisha), lying close to the eastern-most end of the Eastern ghats (India). Located in the Mahanadian Biogeographical Region and within the Biotic Province, Chhotanagpur Plateau, Similipal is the richest watershed in Odisha (India) giving rise to 


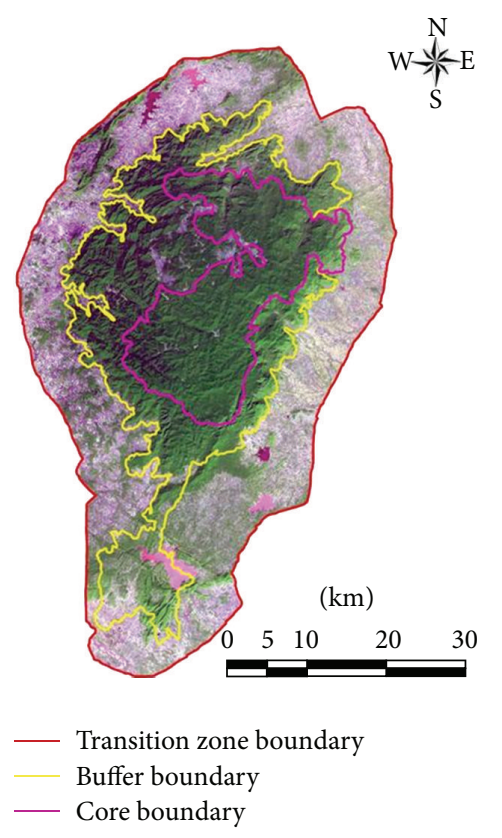

FIGURE 1: Natural colour composition of the SBR along with core, buffer, and transition boundaries.

many perennial rivers like the Budhabalanga, Hadkei, Khairi, Bhandan, West Deo, Salandi, East Deo, Sanjo, and Palpalá. This biosphere reserve is unique in many respects; notable among these are its flora, fauna, landscapes, tribes, and waterfalls.

Most of the people within the Biosphere Reserve have a very low level of skill. Agriculture is not well developed and employment opportunities are very poor. Most of the local inhabitants of the reserve derive their livelihood and income from the forest wood and products. This has led to an undue pressure on wildlife too. Therefore, there is an urgent need to monitor the temporal and spatial status of the forest reserves. With this background, the present investigation was carried out with the broad objective to study the changes taking place in the vegetation density of different areas of high anthropological pressure in the Similipal Biosphere Reserve (SBR) for over a period of 30 years.

\section{Materials and Methods}

2.1. Study Area. The Similipal is a densely forested hill range in the heart of District Mayurbhanj (Odisha, India) and located between $20^{\circ} 17^{\prime}$ and $22^{\circ} 34^{\prime}$ north latitude and $85^{\circ} 40^{\prime}$ and $87^{\circ} 10^{\prime}$ east longitude. Similipal is unique in many respects, notable among which are its flora, fauna, landscapes, waterfalls, and native tribal population. The landscape is beautifully scattered with numerous small and high hills densely covered with vegetation. The highest mountain peak is Khairiburu which is approximately $1168 \mathrm{~m}$, above the sea level. Similipal is the richest watershed in the state of Odisha giving rise to many perennial rivers. Natural colour composite of the SBR along with core, buffer, and transition boundaries is presented in Figure 1. People residing in the Reserve
TABLE 1: Area and status of SBR since 1979.

\begin{tabular}{lcl}
\hline Zone & Area $(\mathrm{sq} \mathrm{km})$ & Status \\
\hline Core & 845 & Sanctuary from 1979 \\
Buffer & 2129 & National park $(1980 / 1986)$ \\
Transition & 2595 & Sanctuary from 1979 \\
\hline
\end{tabular}

area are largely tribal. Due to low level of skills, lower educational levels, and sociocultural traits, they are mainly dependent on local resources. There are four villages inside the core, namely, Kabatghai, Jenabil, Jamunagarh, and Bakua. There are 61 villages in the buffer zone. The climate of the area is monsoonal and divisible into three seasons: summer (March-June), rainy (July-October), and winter (NovemberFebruary). Premonsoon showers are received during May and June. Postmonsoon showers are received during November and December. The natural vegetation is moist deciduous type [20] and is dominated by Shorea robusta, Anogeissus latifolia, Buchanania lanzan, Dillenia pentagyna, Syzygium cumini, and Terminalia alata. The area and status of SBR since 1979 are presented in Table 1. Similipal was declared as a biosphere reserve by Government of India on June 22 1994, due to its rich biodiversity and natural heritage. There are 1076 plants recorded from the area including 60 species of ferns, 92 species of orchids, and two gymnosperms [21, 22]. Our study sites were located in places of high anthropological pressure zones in order to evaluate the impact of human induced disturbances on the vegetation density. Four core villages along with buffer region surrounding roads and higher elevation points were selected for this study.

2.2. Data Source and Materials. We used time series Landsat images as the primary data source for derivation of generalized landcover information. Landsat images provided multispectral data from the early 1970s to 2005. The spatial resolution of Landsat data was appropriate to provide a general landscape characterization and change analysis instead of detailed vegetation and resource mapping. As the intent of this study was to reveal the general trends of landcover change and landscape context, the difference in spatial resolution between MSS (Multispectral Scanner) and TM (Thematic Mapper)/ETM ${ }^{+}$(Enhanced Thematic Mapper) images was not a concern as long as we obtained areas of different vegetation density classes. All the Landsat images were obtained from Global Land Cover Facility (GLCF) and were used to classify the vegetation density in terms of NDVI in the study area. The details of the images used are given in Table 2. All the landsat images were acquired during the dry season, which enabled us to ensure that the images were completely cloud-free and also allowed us to differentiate forest from nonforest areas, with a greater degree of accuracy. All image processing was carried out using the ERDAS Imagine (Earth Resources Data Analysis System) image processing software. The biosphere was delineated into core, buffer, and transition zones as per the map provided by the State Forest Department. The ancillary information was collected by Anthropological Survey of India, Kolkata. 
TABLE 2: Details of the Landsat images used in the study.

\begin{tabular}{lccc}
\hline Satellite/sensor & Path/row & Date & Spatial resolution \\
\hline Landsat/MSS & $150 / 045$ & November 19, 1975 & 56 \\
Landsat/TM & $139 / 045$ & November 21, 1990 & 30 \\
Landsat/TM & $139 / 045$ & November 14, 2005 & 30 \\
\hline
\end{tabular}
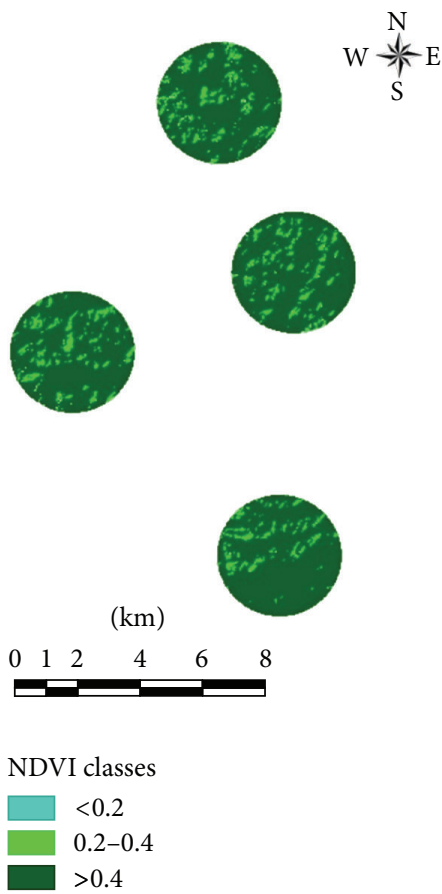

FIGURE 2: Vegetation density map in terms of NDVI classes in $5 \mathrm{~km}$ buffer area surrounding the highest elevation points for 1975.

Topographic maps of Survey of India with scale of $1: 50,000$ were used mainly for geometric correction of the satellite images and for some ground truth information.

2.3. Geometric Correction. After atmospheric correction and elimination of offset value of satellite data, in order to prepare two or more satellite images for an accurate detection of change and comparison, it is imperative to geometrically rectify the imagery. For accurate registration of the different time periods, the images were georeferenced to the Universal Transverse Mercator (UTM) projection and WGS84 datum using 40-45 ground control points (GCPs) with a root mean square error not exceeding 0.5 pixels [23]. Accordingly, the 2005 image was used as the base image to more precisely georeference the other scenes. The correction was made using first order polynomial transformation model and nearest neighbor method for resampling [23]. The geo-referenced images were then clipped with vector masks for the transition, buffer and core boundary to generate the areas of interest.

\section{Results and Discussion}

3.1. Generation of NDVI Image. The normalized difference vegetation index (NDVI) is strongly correlated to the green
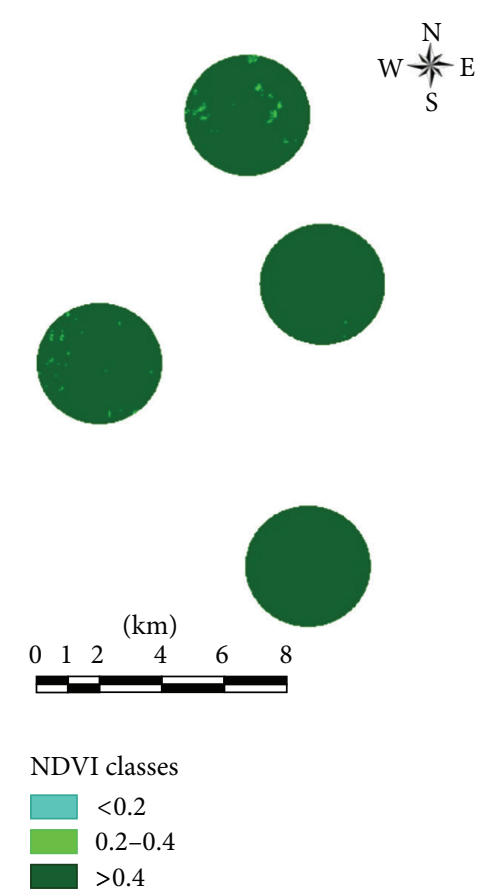

FIGURE 3: Vegetation density map in terms of NDVI classes in $5 \mathrm{~km}$ buffer area surrounding the highest elevation points for 2005.
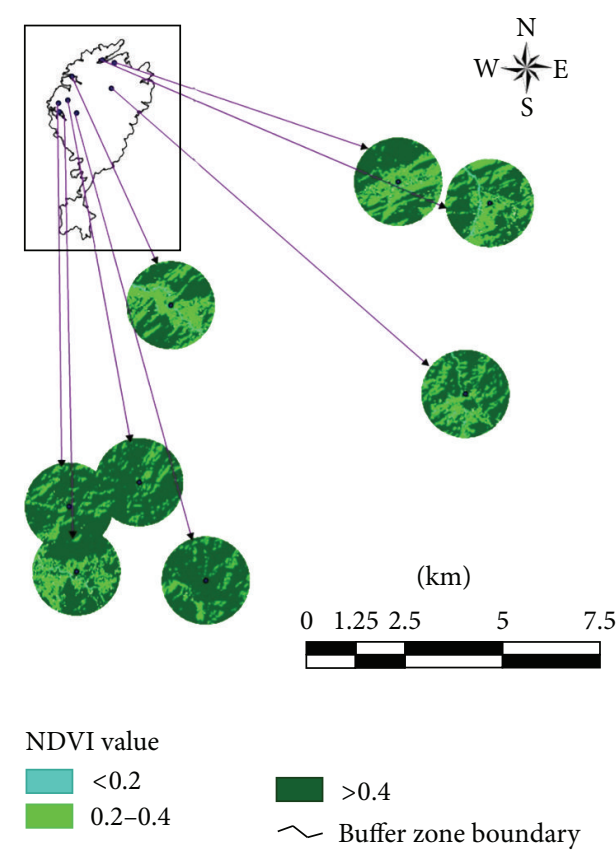

FIGURE 4: Vegetation density map in terms of NDVI classes in $3 \mathrm{~km}$ buffer area surrounding dense road points for 1975.

leaf biomass [24] and calculated by the following formula: NDVI $=(I R-R) /(I R+R)$, where IR refers to infrared light and $\mathrm{R}$ refers to red light [25]. For its measurement, scientists use satellite sensors that observe the distinct wavelengths of visible and near-infrared sunlight which is absorbed and reflected by the plants. Then the ratio of visible and nearinfrared light reflected back up to the sensor is calculated. 

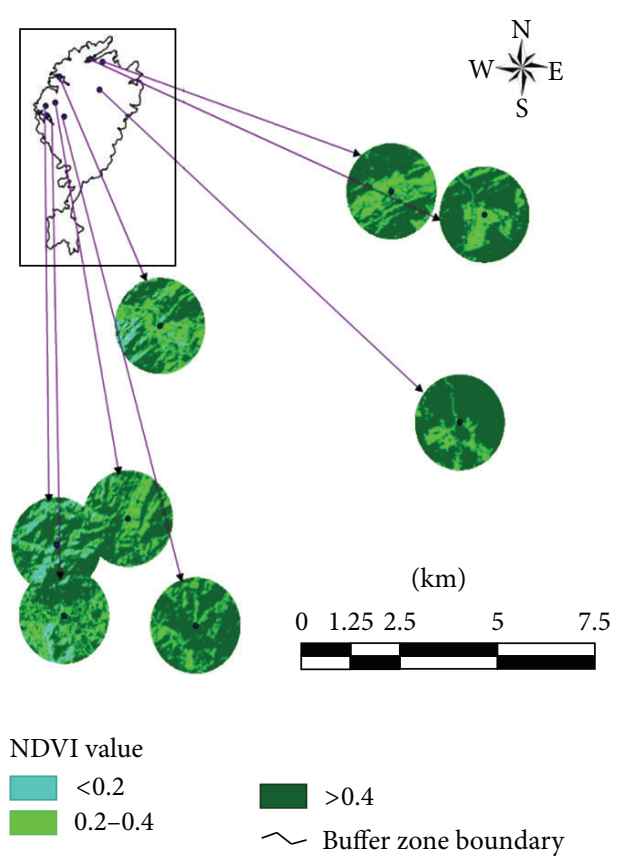

FIGURE 5: Vegetation density map in terms of NDVI classes in $3 \mathrm{~km}$ buffer area surrounding dense road points for 2005.

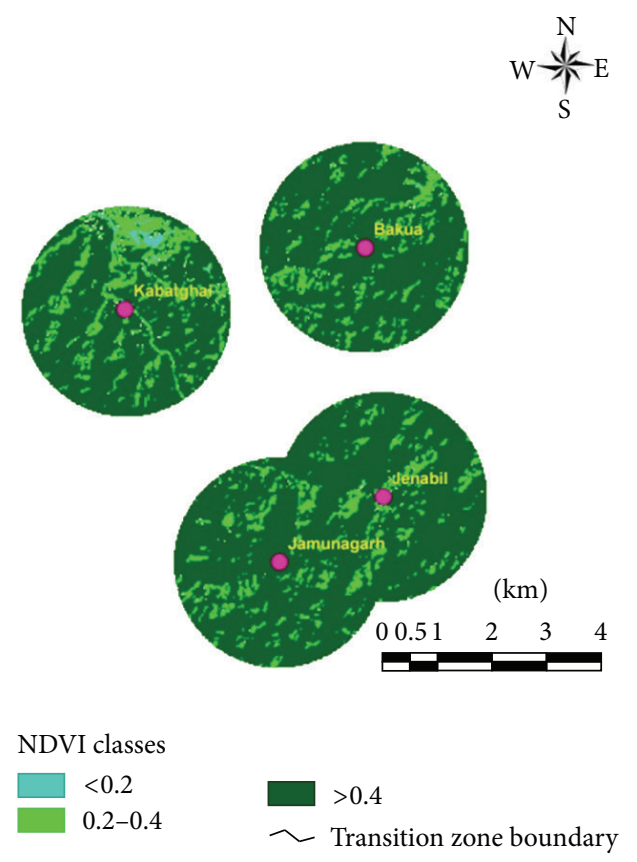

FIGURE 6: Vegetation density map in terms of NDVI classes in $5 \mathrm{~km}$ buffer area surrounding Bakua, Jenabil, Jamunagarh, and Kabatghai villages in SBR for 2005.

The ratio gives a number from minus one $(-1)$ to plus one $(+1)$. An NDVI value of zero means no green vegetation and close to $+1(0.8-0.9)$ indicates the highest possible density of green leaves. The group of pixels having NDVI values from 0 to 0.2 were categorized under canopy density class of $<10 \%$ and $0.2-0.4$ as canopy density class of $10-40 \%$ and, the group
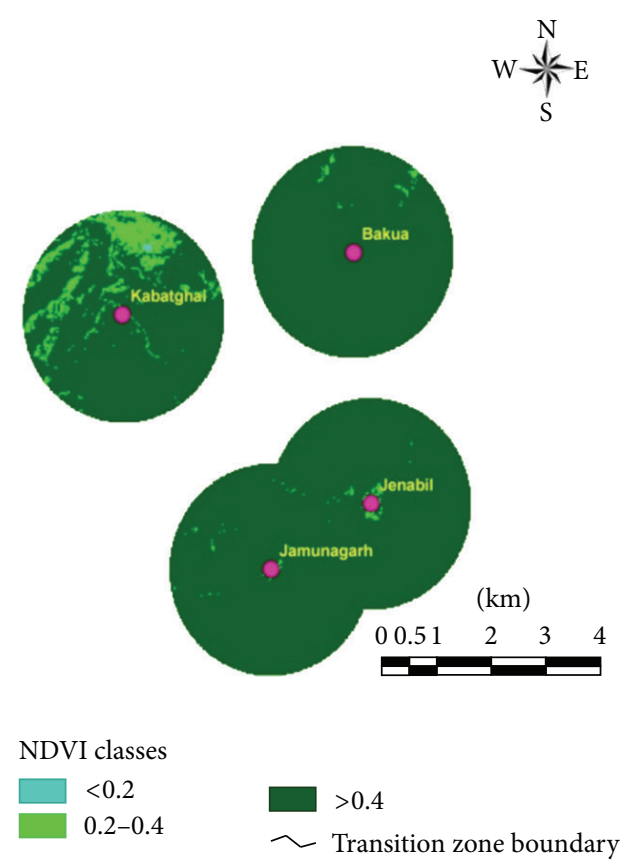

FIGURE 7: Vegetation density map in terms of NDVI classes of $5 \mathrm{~km}$ buffer area surrounding Bakua, Jenasbil, Jamunagarh, and Kabatghai for 2005.

of pixels having NDVI value $>0.4$ were kept under the canopy density class of $40 \%$. Normalized difference vegetation index (NDVI) was used to prepare a forest density map that was categorized into three canopy density classes: $<10 \%$ (nonforest), $10-40 \%$ (open), and $>40 \%$ (medium/high/very high) depending on the NDVI value. Image elements like tone, texture, shape, size, shadow, location, and association were also evaluated to aid in the class delineations.

There are many techniques for the detection of change(s) ranging from visual comparison to detailed quantitative approaches [26]. The fact that sums and differences of bands are used in the NDVI rather than absolute values makes the NDVI more appropriate for use in studies where comparisons over time for a single area are involved. This is because the NDVI might be expected to be influenced to a lesser extent by variation in atmospheric conditions. An assessment of change of vegetation cover in terms of NDVI between 1975, 1990, and 2005 was conducted using an analysis involving detection of postclassification change(s), and the results are presented in Tables 3 and 4 and Figures 4 and 5.

3.2. High Elevation Points. The higher elevation points/places are supposed to be sacred places of worship and other activities for tribal people living inside the forest. For this purpose, $4 \mathrm{~km}$ buffer area surrounding the higher elevation points was selected for analysis. It is observed that the area under $<0.2-0.4$ class has decreased greatly over the years (Table 3, Figures 2 and 3). During the same period, the area under $>0.4$ NDVI class has increased though by approximately 1,000 ha, yet only marginally if examined in terms of percent increase. This shows that less dense forest area has undergone deforestation to a greater extent, whereas 
TABLE 3: Area occupied by different NDVI classes in different years in the $4 \mathrm{~km}$ buffer zones surrounding high elevation points in SBR.

\begin{tabular}{lccc}
\hline \multirow{2}{*}{ NDVI class } & \multicolumn{3}{c}{ Area (ha) occupied in different years } \\
& 1975 & 1990 & 2005 \\
\hline$<0.2$ & 6.48 & 0 & 0.36 \\
$0.2-0.4$ & 1172.52 & 55.44 & 63.36 \\
$>0.4$ & 10321.9 & 11358.9 & 11479 \\
\hline
\end{tabular}

TABLE 4: Area occupied by different NDVI classes in different years in the $3 \mathrm{~km}$ buffer area surrounding dense road points in SBR.

\begin{tabular}{lccc}
\hline \multirow{2}{*}{ NDVI class } & \multicolumn{3}{c}{ Area (ha) occupied in different years } \\
& 1975 & 1990 & 2005 \\
\hline$<0.2$ & 445.32 & 360.72 & 1474.2 \\
$0.2-0.4$ & 5534.64 & 5460.84 & 5554.08 \\
$>0.4$ & 15918.5 & 16345.6 & 15359.4 \\
\hline
\end{tabular}

marginal reforestation occurred in the more dense forest area. It is indicated from the results that anthropological activities did cause deforestation in the less dense forest areas but have not caused deforestation in highly dense vegetative area.

3.3. Buffer Area Surrounding the Road. The area under $<0.2$ class has increased more than threefold over the years in the buffer zone, whereas the area under NDVI class 0.2-0.4 and >0.4 class has remained almost constant (Table 4 and Figures 4 and 5). This shows that less dense forest area has undergone deforestation whereas medium dense forest areas have remained almost constant. However, high dense forest areas surrounding the major roads inside the biosphere reserve have decreased marginally over a period of 30 years. In the area surrounding the roads, anthropological intervention seemed to have increased threefold in less dense forest areas since 1975 through 2005. However, it remained constant in medium dense forest areas and marginally increased in highly dense forest areas.

3.4. Buffer Area Surrounding Four Core Villages. Four core villages, namely, Bakua, Jenabil, Jamunagarh, and Kabatghai, are located inside the core zone of the biosphere reserve. Five $\mathrm{km}$ buffer area surrounding each of these villages has been analysed for studying the change in vegetation density as expressed in terms of NDVI over a period of 30 years. The results are presented in Table 5 and Figures 6 and 7.

The five $\mathrm{km}$ buffer areas surrounding all the four core villages present a very good picture of human-nature coexistence and irrespective of human settlement; there has been an increase in the vegetation density. In all the villages, there is tremendous decrease in the area under $<0.2$ NDVI class and in fact zero in three villages. These areas are mostly covered by dense vegetation $(>0.4)$ throughout the decadal period. The buffer area surrounding all the four villages shows a sign of greening up as the area under $>0.4$ NDVI class increased to a maximal extent which constitutes the maximal proportion of area of analysis.
TABLE 5: Area occupied by different NDVI classes in different years in the $5 \mathrm{~km}$ buffer area surrounding four villages in SBR.

\begin{tabular}{lccc}
\hline \multirow{2}{*}{ NDVI class } & \multicolumn{3}{c}{ Area (ha) occupied in different years } \\
& 1975 & 1990 & 2005 \\
\hline Village: Bakua & & & \\
$\quad<0.2$ & 7.2 & 0 & 0 \\
$0.2-0.4$ & 669.96 & 45.45 & 37.44 \\
$>0.4$ & 4390.92 & 5016.6 & 5064.12 \\
Village: Jenabil & & & \\
$\quad<0.2$ & 8.28 & 0 & 0 \\
$0.2-0.4$ & 568.44 & 50.85 & 40.68 \\
$>0.4$ & 4491.36 & 5012.01 & 5059.44 \\
Village: Jamunagarh & & & \\
$\quad<0.2$ & 3.96 & 0 & 0 \\
$0.2-0.4$ & 632.16 & 24.84 & 28.08 \\
$>0.4$ & 4435.56 & 5038.83 & 5072.4 \\
Village: Kabatghai & & & \\
$<0.2$ & 122.4 & 0.81 & 17.64 \\
$0.2-0.4$ & 956.52 & 370.53 & 672.48 \\
$>0.4$ & 3940.92 & 4687.38 & 4411.08 \\
\hline
\end{tabular}

\section{Conclusion}

Based on the analysis of postclassification changes observed from the time series landsat images it was inferred that the high dense forest in the core zone has been conserved and the highest reforestation had also occurred in this zone of SBR. Over the years, forest density in terms of NDVI, as evidenced from the time series Landsat images, has increased as the area under $>0.4$ NDVI class has shown a positive trend throughout the zones of analysis. This also indicates that anthropological interventions are more in the less dense forest areas and along the roads, whereas high dense forest areas have remained undisturbed and rejuvenated. Further study involving extensive field work and survey is suggested for the analysis of species level vegetation change(s) based on high resolution satellite images.

\section{Acknowledgments}

This work is collaboratively carried out by Regional Remote Sensing Centre, East, NRSC, ISRO, and Anthropological Survey of India, Kolkata. The authors are grateful to the Chief General Manager, Regional Centre, NRSC, ISRO, and Director, ASI, for their valuable support and guidance throughout this study. The authors declare that there is no conflict of interests regarding the publication of this paper.

\section{References}

[1] J. F. Brown, T. R. Loveland, J. W. Merchant, B. C. Reed, and D. O. Ohlen, "Using multisource data in global landcover characterization: concepts, requirements, and methods," Photogrammetric Engineering \& Remote Sensing, vol. 59, no. 6, pp. 977-987, 1993. 
[2] D. L. Evans, Z. Zhu, and K. Winterberger, "Mapping forest distributions with AVHRR data," World Resource Review, vol. 5, pp. 66-71, 1993.

[3] T. R. Loveland, J. W. Merchant, D. O. Ohlen, and J. F. Brown, "Development of a land-cover characteristics database for the conterminous US," Photogrammetric Engineering \& Remote Sensing, vol. 57, no. 11, pp. 1453-1463, 1991.

[4] J. R. G. Townshend, "The $1 \mathrm{~km}$ resolution global data set: needs of the International Geosphere Biosphere Programme," International Journal of Remote Sensing, vol. 15, no. 17, pp. 34173441, 1994.

[5] T. Fung and W. S. Siu, "Environmental quality and its changes, an analysis using NDVI," International Journal of Remote Sensing, vol. 21, no. 5, pp. 1011-1024, 2000.

[6] X. Jiang, Q. Wan, L. Du, and B. X. Hu, "Estimation of NDVI images using geostatistical methods," Earth Science Frontiers, vol. 15, no. 4, pp. 71-80, 2008.

[7] J. Wang, K. P. Price, and P. M. Rich, "Spatial patterns of NDVI in response to precipitation and temperature in the central Great Plains," International Journal of Remote Sensing, vol. 22, no. 18, pp. 3827-3844, 2001.

[8] Q. Weng, D. Lu, and J. Schubring, "Estimation of land surface temperature-vegetation abundance relationship for urban heat island studies," Remote Sensing of Environment, vol. 89, no. 4, pp. 467-483, 2004.

[9] G. Asrar, R. B. Myneni, and B. J. Choudhury, "Spatial heterogeneity in vegetation canopies and remote sensing of absorbed photosynthetically active radiation: a modeling study," Remote Sensing of Environment, vol. 41, no. 2-3, pp. 85-103, 1992.

[10] S. N. Goward and K. F. Huemmrich, "Vegetation canopy PAR absorptance and the normalized difference vegetation index: an assessment using the SAIL model," Remote Sensing of Environment, vol. 39, no. 2, pp. 119-140, 1992.

[11] P. J. Sellers, "A global $1^{\circ}$ by $1^{\circ}$ NDVI data set for climate studies. Part 2: the generation of global fields of terrestrial biophysical parameters from the NDVI," International Journal of Remote Sensing, vol. 15, no. 17, pp. 3519-3545, 1994.

[12] S. D. Prince, "A model of regional primary production for use with coarse resolution satellite data," International Journal of Remote Sensing, vol. 12, no. 6, pp. 1313-1330, 1991.

[13] S. W. Running and R. R. Nemani, "Relating seasonal patterns of the AVHRR vegetation index to simulated photosynthesis and transpiration of forests in different climates," Remote Sensing of Environment, vol. 24, no. 2, pp. 347-367, 1988.

[14] C. J. Tucker and P. J. Sellers, "Satellite remote sensing of primary production," International Journal of Remote Sensing, vol. 7, no. 11, pp. 1395-1416, 1986.

[15] C. P. Lo, "Application of Landsat TM data for quality of life assessment in an urban environment," Computers, Environment and Urban Systems, vol. 21, no. 3-4, pp. 259-276, 1997.

[16] S. Myeong, D. J. Nowak, and M. J. Duggin, "A temporal analysis of urban forest carbon storage using remote sensing," Remote Sensing of Environment, vol. 101, no. 2, pp. 277-282, 2006.

[17] N. C. Coops, M. A. Wulder, and D. Iwanicka, "Demonstration of a satellite-based index to monitor habitat at continental-scales," Ecological Indicators, vol. 9, no. 5, pp. 948-958, 2009.

[18] A. Hassini, N. Benabadji, and A. H. Belbachir, "AVHRR data sensor processing," Journal of Applied Sciences, vol. 6, no. 11, pp. 2501-2505, 2006.

[19] J. A. Sobrino and N. Raissouni, "Toward remote sensing methods for land cover dynamic monitoring: application to Morocco," International Journal of Remote Sensing, vol. 21, no. 2, pp. 353-366, 2000.
[20] H. G. Champion and S. K. Seth, A Revised Survey of the Forest Types of India, Government of India Press, New Delhi, India, 1968.

[21] H. O. Saxena and M. Brahmam, The Flora of Similipahar, Orissa, Regional Research Laboratory, Bhubaneswar, India, 1989.

[22] S. Misra, Orchids of Orissa, Bishen Singh Mahendra Pal Singh Publication, Dehra Dun, India, 2004.

[23] R. S. Lunetta and C. D. Elvidge, Remote Sensing Change Detection: Environmental Monitoring Methods and Applications, Ann Arbor Press, Chelsea, Mich, USA, 1998.

[24] C. J. Tucker, "Red and photographic infrared linear combinations for monitoring vegetation," Remote Sensing of Environment, vol. 8, no. 2, pp. 127-150, 1979.

[25] T. M. Lillesand and R. W. Kiefer, Remote Sensing and Image Interpretation, John Wiley and Sons, Toronto, Canada, 1994.

[26] G. M. Wickware and P. J. Howarth, "Change detection in the Peace-Athabasca delta using digital Landsat data," Remote Sensing of Environment, vol. 11, pp. 9-25, 1981. 

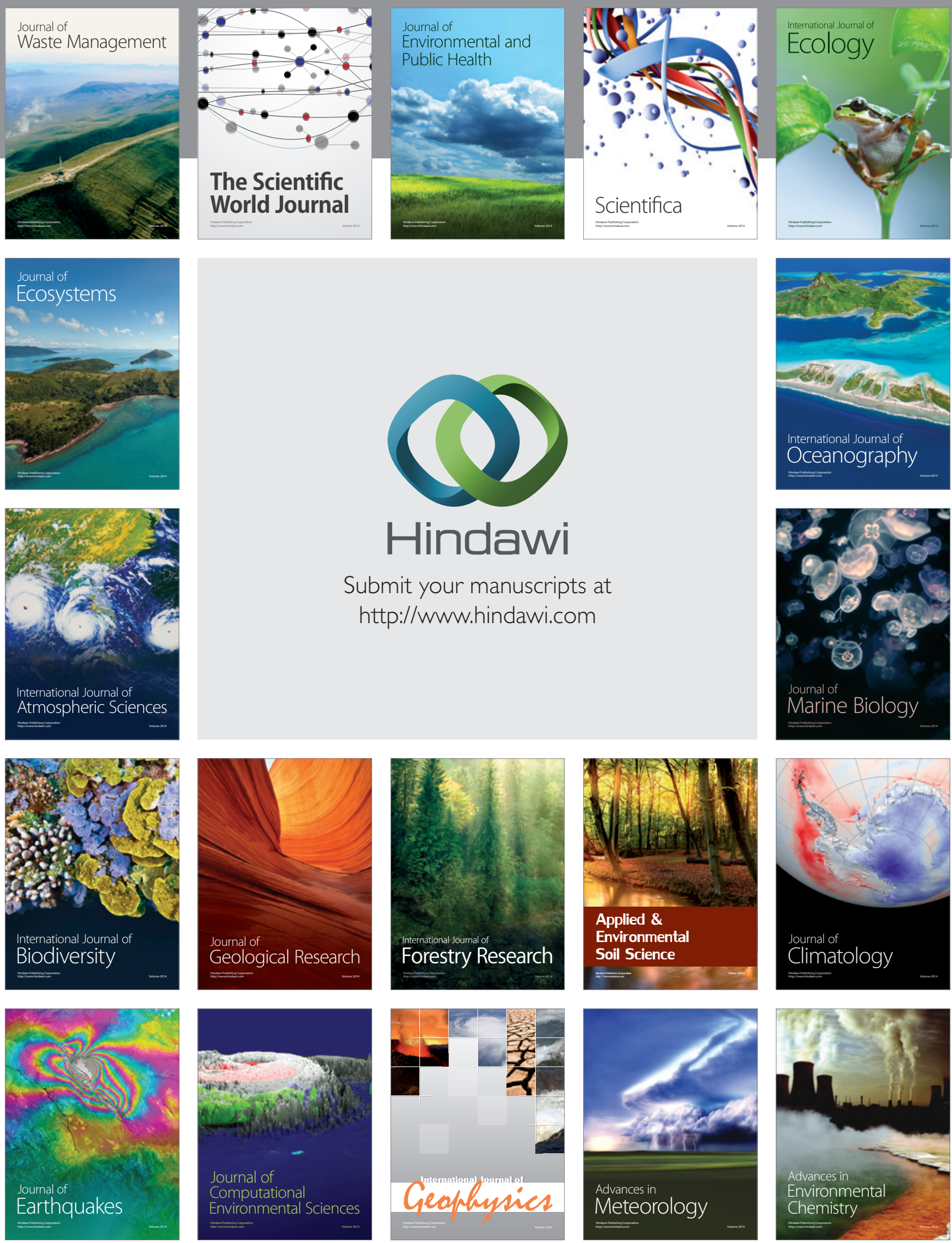